\title{
Can Autistics Identify with Jake Barnes? The Case of Autism and the Hemingway Narrator in the Sun Also Rises
}

\author{
John Marinan ${ }^{1}$ \\ ${ }^{1}$ Georgia Gwinnett College, Department of English, University Center Lane, Lawrenceville, GA, USA \\ Correspondence: John Marinan, Georgia Gwinnett College, Department of English, University Center Lane, \\ Lawrenceville, GA, 30043, USA. Tel: 1-470-217-5148. E-mail: jmarinan1@niu.edu
}

Received: September 21, 2015

Accepted: October 13, $2015 \quad$ Online Published: November 10, 2015

doi:10.5539/ijps.v7n4p106

URL: http://dx.doi.org/10.5539/ijps.v7n4p106

\section{Introduction}

A growing theme in Hemingway studies is disability. Recent scholarship has drawn attention to disability in "Hemingway heroes", including Jake Barnes, the main character of The Sun Also Rises (Note 1). Jake Barnes's disability is leveraged artistically by Hemingway into narrative incommunicability. This incommunicability looks like autism in its narrative presentation.

Hemingway is not the first author to utilize autistic symptomatology to describe his main characters. Although the term "autism" (Note 2) was coined with the publication of Eugen Bleuler's Dementia Praecox (1911), there are suggestions of it in prior literary work. In the 1800s, Herman Melville wrote Bartleby the Scrivener, featuring a character whose famous line was that he "would prefer not to" (Note 3). Bartleby's queer personality and standoffishness have led to critical descriptions of his potential autism. (Note 4) Hemingway was aware of the power of an incommunicative narrator, the classic tabula rasa to redirect the emotions and feelings of other characters. Ernest Hemingway was expert in the use of emotionally incommunicative narrator for his creative purposes.

The purpose of this paper is to determine if an autistic reader could actually understand a narrator like Jake Barnes because his "revelation quality" is so low. Would an autistic person be able to appreciate a fictional account where the narration is difficult, and by what means would they be able to do so? I will contextualize the discussion with contributions from Lisa Zunshine, whose adaptation of Baron-Cohen's mindblindness theory is particularly relevant. In addition, I will provide some background on the narrative concept of paralipsis, which describes Hemingway's narrative style. I will perform a close reading of The Sun Also Rises to illustrate the components of Jake Barnes's "autistic narration". Finally, I will look to Kenneth Burke's concept of identification to argue that autistics, based on shared characteristics with Hemingway's narrator, are better placed to understand this type of narration because of their shared set of communicative characteristics.

\section{Theory of Mind and Fiction}

Cognitive psychology has contributed to the discussion of autistic reading of fictional accounts. Lisa Zunshine has extended the work of Simon Baron-Cohen's mindblindness theory which states that autistic people have a hard time reading minds and therefore understanding fictional accounts. Zunshine and Baron Cohen argue that some people on the autistic spectrum, due to their lack of T.O.M.M. (Theory of Mind Mechanism), cannot understand narration because the narrator does not often tell the truth about his or her characters. According to Zunshine:

Mind-reading is a term used by cognitive psychologists, interchangeably with "Theory of Mind," to describe our ability to explain people's behavior in terms of their thoughts, feelings, beliefs, and desires. Thus we engage in mind-reading when we ascribe to a person a certain mental state on the basis of her observable action; when we interpret our own feelings based on our proprioceptive awareness; when we intuit a complex state of mind based on a limited verbal description; when we compose an essay, a lecture, a movie, a song, a novel, or an instruction for an electrical appliance...; when we negotiate a multilayered social situation; and so forth (Note 5). 
As you can see, Zunshine uses Theory of Mind ideas in connection with texts, such as "movies, songs, novels, or instructions" (Note 6). While Baron-Cohen metaphorically connects the "mind as computer" to autism, Zunshine crucially extends the metaphor to texts. This connection has implications for autistics and for fiction readers.

Zunshine believes that mind-reading is the ability to intuit a complex state of mind based on a limited verbal description. Hemingway's narrator Jake Barnes says little but intends much. As a result, according to Zunshine, audiences with normal "endowments" are able to mind-read fictional characters while people with autism, or cognitive deficits, are not. Thus, narrative descriptions with less detail would expose autistics to difficulties in their interpretations. Zunshine extends this hypothesis further. She states, "Perhaps fiction presents a challenge to people with autism because in many ways it calls for the same kind of mind-reading - that is, the inference of the mental state from the behavior - that is necessary in regular human communication" (Note 7). Zunshine's justification for her remarks is based on cognitive biology. She argues that "the cognitive mechanisms that evolved to process information about thoughts and feelings of human beings are constantly on the alert, checking our environment for cues that fit their input conditions" (Note 8). Thus, Zunshine likens the reading of texts to a form of communication between reader and text. However, in order for the communication to function properly, the reader must be endowed with certain attributes that autistics do not have, "works of fiction manage to "cheat" these mechanisms into "believing" that they are in the presence of material that they are "designed" to process, that is, that they are in the presence of agents endowed with a potential for a rich array of intentional stances" (Note 9). According to Zunshine, there must be a presence of agents endowed with a potential for a rich array of intentional stances. Since many autistic readers have an impaired functioning of T.O.M.M., their array of intentional stances would not allow them to interact with fiction in the same way as neurotypical readers.

\section{Autism and Its Connection to Paralipsis}

Using Hemingway's text The Sun Also Rises would be an extreme example of an opaque fictional text. If some autistic readers would have difficulty reading fiction, how would they read an opaque narrator whose object is to conceal information and mental states so critical to interpretation?

Hemingway's use of an autistic-like narrator is based in the rhetorical concept of paralipsis. This rhetorical technique, derived from the Greeks, was often used by politicians in ad hominem attacks on their opponents. An example of paralipsis would be as follows: "I won't even discuss the baseless accusations that my opponent is a drunk." On the surface, the politician appears to be defending his opponent from rash insinuations against his character. However, the addition of the word "drunk" adds destructive value and reinforces negative connotations all the same. Paralipsis is the device of giving emphasis by professing to say little or nothing about a subject.

Jake Barnes and paralipsis are practically synonymous. His omissions are a crucial aspect of Hemingway's storytelling. Hemingway discusses the idea of omission in his own words:

If a writer of prose knows enough of what he is writing about he may omit things that he knows and the reader, if the writer is writing truly enough, will have a feeling of those things as strongly as though the writer had stated them. The dignity of movement of an ice-berg is due to only one-eighth of it being above water. A writer who omits things because he does not know them only makes hollow places in his writing (Note 10).

Hemingway argues that omission can be an effective writing strategy. He assumes that the reader will figure out what he is intending through his narrator. In Hemingway, the demands on the reader to interpret characters and their emotional involvements are high due to his narrative style.

\section{Close Reading of the Sun Also Rises}

I will perform a close reading of Jake Barnes as opaque narrator to uncover these paraliptic tendencies. There are many textual examples of Jake Barnes as incommunicative narrator. At issue is the lack of internal dialogue or outward discussion of his lost manhood. Jake states:

I lay awake thinking and my mind jumping around. Then I couldn't keep away from it, and I started to think about Brett and all the rest of it went away. I was thinking about Brett and my mind stopped jumping around and started to go in sort of smooth waves. Then all of a sudden I started to cry. Then after a while it was better and I lay in bed and listened to the heavy trams go by and way down the street, and then I went to sleep (Note 11).

Notice that there is a short description of a major scene from the narrator. Jake describes his mind as "jumping around" but he can't, or won't, describe his emotional content. While Jake's crying jag denotes some emotional response, his narrative description is surface-like in its explication. He just listens to trains and falls asleep 
without really telling the audience anything about his feelings. We are left to deposit our own emotional arsenal onto the scene.

While paralipsis is a focal-point of Hemingway's narrative, it differs greatly from other famous American literature in its narration. Let's contrast the above quotation from Hemingway with Huck Finn, a more direct first-person narrator:

The Widow Douglas she took me for her son, and allowed she would sivilize me; but it was rough living in the house all the time, considering how dismal regular and decent the widow was in all her ways; and so when I couldn't stand it no longer I lit out. I got into my old rags and my sugar-hogshead again, and was free and satisfied. But Tom Sawyer he hunted me up and said he was going to start a band of robbers, and I might join if I would go back to the widow and be respectable. So I went back (Note 12).

Here is an explanation by Huck which includes the widow Douglas's intentions towards him, his emotions regarding his departure, and his desire to return home. The tone is conversational; Huck explains his feelings of constraint to the audience, and we see the humor in his being convinced to come back to the Widow Douglas. Huck reveals pretty much everything he feels to the readers. There are no secrets. This passage is in direct contrast with Hemingway's passage regarding Jake Barnes, who for whatever reason cannot reveal himself in the same way. Huck does not see himself as needing to hide anything from us. Twain's narrative strategy relies on frankness for its humor and charm, whereas Jake Barnes relies on omission so the reader can make the emotional connections.

In The Sun Also Rises, Jake Barnes clearly suffers from past events. He elides or suppresses his feelings and focuses on the materiality of the scenes, privileging the objective over the subjective. This is an example of autistic-like behavior, as well as paralipsis. Here is an example:

I looked at myself in the mirror of the big armoire beside the bed. That was a typically French way to furnish a room. Practical, too, I suppose. Of all the ways to be wounded. I suppose it was funny (Note 13).

Barnes downplays his genital wound by changing the subject. He intersperses deep emotional content with descriptions of furniture and its practicality. His comment about the funny nature of a genital wound that in effect destroys his manhood and search for meaningful relationships is the reaction of an emotionally absent individual. Hemingway's paraliptic narration comes off like the expression of an autistic man struggling with the interpersonal skills and the words to describe his situation.

Another example of Jake's autistic behavior is his inability to read social situations. Jake and Brett are talking about her recent rendezvous with Robert Cohn, which enrages Jake. After Brett tells Jake that she had gone off with Cohen, he expresses extreme surprise. Even Brett, who is as open with her sexuality as she is promiscuous, states, "Didn't you really know?" (Note 14). Jake's response is, "No, I guess I didn't really think about it" (Note 15). Jake either doesn't see Brett as a sexual object for anyone other than himself or has mindblindness characteristics, unable to see romantic situations and Brett's promiscuity for what it really is. His level of anger is in indirect proportion to his level of understanding of the nuances of his friendship with Brett.

\section{Autistic Adaptations to Fictional Situations}

There is documented evidence of autistic people making adaptations in social situations in order to understand dialogue. Temple Grandin is an example; she reads about people, and observes them, in an attempt to arrive at the various principles that would explain and predict their actions in what she describes as "a strictly logical process" (Note 16). Perhaps Grandin cannot immediately empathize with a character. She reads about characters like the character she is reading about and then processes the information in order to make a successful judgment about him/her. In other words, she decodes emotional behavior (Note 17).

On an ontological level, autistics could relate to Jake Barnes because of the fundamental recognition of sameness as humans. Despite the difficulty of understanding what a war wound would feel like, autistic audiences would accept the idea that Jake is damaged, traumatized, and trying to make sense of his past in order to accept his future. In other words, there is more to recognition and empathy than words, and this applies to fiction as well as conversational interactions. Hemingway's paraliptic narration withdraws some details of Jake's personhood, but leaves enough so that he can be recognized. 


\section{Burkean Identification: How Autistics Can Understand Fiction}

Autism is a rhetorical phenomenon. Melanie Yergeau cites Burke's definition of rhetoric as inducing human agents to develop or create social actions. She also defines autism as impaired social interaction. Thus there is a clear link between autism and rhetoric from a definitional standpoint. She links Jim Corder's "being in the world through language" (Note 18), utilizing invention, arrangement, and style with an autistic sense of being in the world through a different type of language, also utilizing invention, arrangement, and the other canons of rhetoric, such as memory, delivery and style. Corder mentions that utterances sometimes get stuck in transit, especially between autistic and non-autistic people.

If it is accepted that autism is a rhetorical phenomenon, then Burke's concept of identification can provide illumination with respect to the fundamental connection between autistic readers and fictional texts. Burke suggests that whenever someone attempts to persuade someone else, identification occurs, because for persuasion to occur, one party must "identify" with another. That is, the one who becomes persuaded sees that he/she is like another in some way. In identifying with the interests of another (or being persuaded that shared interests exist, even if they do not), one is "substantially one" with that other, or consubstantial. If we apply the scenario of an autistic reader analyzing a paraliptic narrator like Jake Barnes, it does not take too much to determine consubstantiality. Burke states:

Insofar as the individual is involved in conflict with other individuals or groups, the study of this same individual would fall under the head of Rhetoric. The Rhetoric must lead us through the Scramble, the Wrangle of the Market Place, the flurries and flare-ups of the Human Barnyard, the Give and Take, the wavering line of pressure and counterpressure, the Logomachy, the onus of ownership, the War of Nerves, the War (Note 19).

According to Burke, the rhetorical notion of identification is tied up with the idea of consubstantiality ("substantially one" with the "other") and also division (conflict with other individuals or groups). Therefore, autistic readers must feel substantially one with Jake Barnes and also understand his conflicts with other individuals or groups in order to identify with him.

\section{Conclusion}

A great deal of research on brain science has indicated that autistic people have deficits in Theory of Mind. According to scholars such as Simon Baron-Cohen, Theory of Mind is necessary for understanding the intentions of others, and autistics lack Theory of Mind. Lisa Zunshine has taken the point further and argued that Theory of Mind can apply to texts as well as interactive situations. If we accept the idea that texts can have an "interpersonal" influence on readers, then it seems logical that texts are also persuasive, and therefore rhetorical. These texts contain characters like Jake Barnes, whose influence is muted through paraliptic narration. However, since the texts are rhetorical, they are persuasive in different ways for different readers. To say that autistic readers cannot understand a character like Jake Barnes is tantamount to saying that autistic people are arhetorical because of their inability to understand the persuasive nature of a text. However, with the application of Burke's idea of identification, there is a significant degree of consubstantiality between Jake Barnes' experience and theirs. The autistic reader can connect their experience of longing and loss with that of Jake. Consequently, the autistic reader, unlike what recent research has suggested, is more able to identify with the complex narrator, not less able, because of the very nature of autism and its complexities with respect to explicit communication.

\section{References}

Baron-Cohen, S. (1999). Mindblindness: An Essay on Autism and Theory of Mind. Cambridge: MIT Press.

Baron-Cohen, S., Tager-Flusberg, H., \& Cohen, D. J. (1993). Understanding Other Minds: Perspectives from Autism. Oxford: Oxford University Press.

Bradbury, M. (2005). The Modern British Novel. Beijing: Foreign Language Teaching and Research.

Burke, K. (1969). A Rhetoric of Motives. Berkeley: University of California Press.

Corder, J. (1984). A New Introduction to Psychoanalysis, Taken as a Version of Modern Rhetoric. Pre/Text, 137-169.

Doody, T. (1974). Hemingway's Style and Jake's Narration. The Journal of Narrative Technique, 212-225.

Duffy, J., \& Dorner, R. (2011). The Pathos of "Mindblindness": Autism, Science, and Sadness in "Theory of Mind" Narratives. Journal of Literaryand Cultural Disability Studies, 201-215. http://dx.doi.org/10.3828/jlcds.2011.16 
Eyal, G. (2013). For a Sociology of Expertise: The Social Origins of the Autism Epidemic. American Journal of Sociology, 863-907. http://dx.doi.org/10.1086/668448

Fundukian, L. J. (2013, April 15). Autism. In Encyclopedia of Public Health (pp. 1-24).

Gallagher, S. (2004). Understanding Interpersonal Problems in Autism: Interaction Theory as an Alternative to Theory of Mind. Philosophy, Psychiatry, and Psychology, 199-217. http://dx.doi.org/10.1353/ppp.2004.0063

Geschwind, D. H. (2011). Genetics of Autism Spectrum Disorders. Trends in Cognitive Sciences, 409-416. http://dx.doi.org/10.1016/j.tics.2011.07.003

Gipps, R. (2004). Autism and Intersubjectivity: Beyond Cognitivism and the Theory of Mind. Philosophy, Psychiatry, and Psychology, 195-198. http://dx.doi.org/10.1353/ppp.2004.0065

Health, N. I. (2015, April 14). PTSD. In Health and Education (pp. 1-6).

Heliker, P., \& Yergeau, M. (2011). Autism and Rhetoric. College English, 485-497.

Hemingway, E. (1926). The Sun Also Rises. New York: Scribner's.

Jahn, M. (2005). Narratology: A Guide to the Theory of Narrative. Cologne: University of Cologne Press.

Love, G. A. (1990). The Professor's House: Cather, Hemingway, and The Chastening of Americn Prose Style. Western American Literature, 295-311.

Matthews, S. (2008). Modernism: A Sourcebook. Basingstoke: Palgrave Macmillan.

Moreland, K. (2003). Just the Tip of the Iceburg Theory: Hemingway and Sherwood Anderson's Loneliness. The Hemingway Review, 47-56.

Neimneh, S. (2013). The Anti-Hero in Modernist Fiction: From Irony to Cultural Renewal. Mosaic: A Journal for the Interdisciplinary Study of Literature, 75-90. http://dx.doi.org/10.1353/mos.2013.0036

Oliver, C. M. (1999). Ernest Hemingway A to Z: The Essential Reference to the Life and Work. New York: Facts on File.

Rouselle, E. (2013). Beyond the Limits of Theory of Mind Analysis: Olga Orozco's "Tierras En Erosion" [Eroding Lands] and First-Hand Accounts of Autism. PsyArt, 1-7.

Smith, P. (1983). Hemingway's Early Manuscripts: The Theory and Practice of Omission. Journal of American Literature, 268-288.

Twain, M. (2010). The Adventures of Huckleberry Finn. Costa Mesa: Saddleback Press.

Zunshine, L. (2006). Why We Read Fiction: Theory of Mind and the Novel. Columbus: Ohio State University Press.

\section{Notes}

Note 1. Alexandra Perry and Chris Herrera, Ethics and Neurodiversity (Newcastle upon Tyne: Cambridge Scholars, 2013), p. 29.

Note 2. Eugen Bleuler, Dementia Praecox: Or, The Group of Schizophrenias (New York: International Universities Press, 1964), 5.

Note 3. Herman Melville, Bartleby the Scrivener: A Story of Wall Street (New York: Simon and Schuster, 1997), 21.

Note 4. Amit Pinchevski, "Bartleby's Autism Wandering Along Incommunicability", Culture Critique, 78, (2001): 27-59, $\quad$ accessed $\quad$ September 15, http://www.jstor.org/stable/10.5749/culturalcritique.78.2011.0027?seq=1\#page_scan_tab_contents.

Note 5. Lisa Zunshine, Why We Read Fiction: Theory of Mind and the Novel (Columbus: Ohio State University Press, 2006), 5.

Note 6. Ibid., 5.

Note 7. Ibid., 9.

Note 8. Ibid., 10.

Note 9. Ibid., 10. 
Note 10. Ernest Hemingway in Charles Oliver, Ernest Hemingway: A-Z: The Essential Reference to the Life and Work (New York: Facts on File, 1999), 322.

Note 11. Ernest Hemingway, The Sun Also Rises (New York: Scribner's, 1926), 39.

Note 12. Mark Twain, The Adventures of Huckleberry Finn. (Costa Mesa: Saddleback, 2010), 1.

Note 13. Ernest Hemingway, The Sun Also Rises (New York: Scribner's, 1926), 38.

Note 14. Ibid., 90.

Note 15. Ibid., 90.

Note 16. Ibid., 212.

Note 17. Ibid., 212.

Note 18. Ibid., 487.

Note 19. Kenneth Burke, A Rhetoric of Motives (Berkeley: University of California Press, 1969), 23.

\section{Copyrights}

Copyright for this article is retained by the author(s), with first publication rights granted to the journal.

This is an open-access article distributed under the terms and conditions of the Creative Commons Attribution license (http://creativecommons.org/licenses/by/3.0/). 